- FINANSE I PRAWO FINANSOWE.

- Journal of Finance and Financial Law •

Czerwiec/June 2017 • vol. 2(14): 53-65

http://dx.doi.org/10.18778/2391-6478.2.14.05

\title{
NIEPRAWIDŁOWOŚCI W OCENIE ZDOLNOŚCI KREDYTOWEJ KLIENTÓW DETALICZNYCH
}

\author{
Paweł Nowak \\ Dr, Instytut Politologii \\ Uniwersytet Pedagogiczny w Krakowie
}

\begin{abstract}
Streszczenie
Prawidłowa ocena zdolności kredytowej leży w interesie kredytodawcy i kredytobiorcy oraz służy stabilności systemu finansowego. W artykule dokonano identyfikacji głównych nieprawidłowości występujących w procesie oceny zdolności kredytowej klientów detalicznych, występujących zarówno po stronie banków jak i klientów. Należą do nich przyjmowanie niskich buforów bezpieczeństwa stóp procentowych, zaniżania kosztów utrzymania, nadmierne wydłużanie okresu kredytowania, zaniedbywanie obowiązków informacyjnych oraz zatajanie informacji przez konsumentów. W tekście znalazły się także propozycje działań korygujących i naprawczych, będących w dyspozycji obu stron rynku, podnoszących skuteczność oceny zdolności kredytowej.
\end{abstract}

Słowa kluczowe: bezpieczeństwo konsumenta, ocena zdolności kredytowej, ochrona konsumenta, rynek finansowania detalicznego.

JEL Class: G21, D18. 


\section{WPROWADZENIE}

Obowiązek oceny zdolności kredytowej ma charakter ustawowy [Ustawa z dnia 29 sierpnia 1997 r. ...; Ustawa z dnia 12 maja 2011 r. ...]. Rzetelnie przeprowadzona ocena zdolności kredytowej jest zarówno w interesie kredytodawcy jak i kredytobiorcy. Zabezpiecza ona strony umowy kredytu przed konsekwencjami braku spłaty zobowiązania i jest warunkiem stabilności systemu finansowego. Ze względu na nierównowagę kontraktową, ma ona szczególnie duże znaczenia dla słabszej strony umowy - konsumenta (klienta detalicznego) [Gnela 2012: 163-178]. Rzetelnie przeprowadzona ocena zdolności kredytowej zabezpiecza konsumentów przed kłopotami finansowymi i nadmiernym zadłużeniem [Knehans-Olejnik 2015: 109-113; Świecka 2009: 145-198; Wałęga 2013: 131-156].

Celem artykułu jest identyfikacja głównych nieprawidłowości występujących $\mathrm{w}$ procesie ocenie zdolności kredytowej klientów detalicznych, występujących zarówno po stronie kredytodawców, jak i kredytobiorców. Stawia się w nim tezę, iż nieprawidłowości w ocenie zdolności kredytowej nie są spowodowane wyłącznie przez kredytodawców, ale powstają z przyczyn mieszanych, zależnych także od kredytobiorców. Tekst zawiera również propozycje działań korygujących i naprawczych, dostępnych dla obu stron rynku, podnoszących skuteczność procesu oceny zdolności kredytowej. Artykuł został oparty na raportach wydanych przez organy nadzoru rynku finansowania detalicznego oraz literaturze przedmiotu.

\section{ISTOTA OCENY ZDOLNOŚCI KREDYTOWEJ KLIENTÓW DETALICZNYCH}

Charakterystycznym trendem w sektorze bankowym jest rosnący udział kredytów detalicznych w portfelach kredytowych banków [Rytelewska i Huszczonek 2004: 34]. Dotyczy to przede wszystkim kredytów mieszkaniowych, które stają się główną dziedziną działalności kredytowej [Małecki 2014: 467-487]. Ponadto pozostałe kredyty detaliczne (kredyty konsumpcyjne), charakteryzują się bardzo wysoką dynamiką sprzedaży. Na koniec 2015 r. w portfelach banków znajdowało się 21,2 mln kredytów konsumpcyjnych o łącznej wartości 133,4 mld zł i średniej wartości 6,3 tys. zł oraz 1,9 mln kredytów mieszkaniowych o łącznej wartości 370 mld zł i średniej wartości 190,2 tys. zł [Raport o sytuacji banków w 2015 r., 2016: 98, dostęp: 15.03.2017]. Jakość portfela kredytowego w 2015 r. pozostawała względnie stabilna a w niektórych obszarach wystąpiło pogorszenie - głównie w kategorii „pozostałe kredyty” gospodarstw domowych, obejmującej kredyty w kartach kredytowych i w rachunkach ROR.

Zgodnie z artykułem 70.1 ustawy Prawo bankowe z dnia 29 sierpnia $1997 \mathrm{r}$. „przez zdolność kredytową rozumie się zdolność do spłaty zaciągniętego kredy- 
tu wraz z odsetkami w terminach określonych w umowie. Kredytobiorca jest obowiązany przedłożyć na żądanie banku dokumenty i informacje niezbędne do dokonania oceny tej zdolności” [Ustawa z dnia 29 sierpnia 1997...].

Poziom zdolności kredytowej klientów detalicznych wyliczany jest przez każdego kredytodawcę na podstawie nieco odmiennego algorytmu i zależy od bardzo wielu czynników. Są to m.in. [Dobosiewicz 2011: 183-196; Wiatr 2001: 595-712; Wójciak 2007: 11-72]:

- wysokość dochodów kredytobiorcy,

- wysokość zamkniętych i otwartych zobowiązań kredytobiorcy, taki jak: kredyty, pożyczki, zadłużenie w kartach kredytowych i rachunkach oszczędnościowo-rozliczeniowych, poręczone kredyty,

- długość okresu kredytowania,

- typ zadeklarowanych we wniosku kredytowym rat,

- waluta kredytu,

- dotychczasowa historia kredytowa.

Banki akceptują różny poziom ryzyka kredytowego. Wpływ na akceptowany poziom ryzyka mają czynniki o charakterze wewnętrznym i zewnętrznym, w tym m.in.: skala oraz rodzaj prowadzonej przez bank działalności, jakość portfela kredytowego banku, zmiany w strukturze detalicznych ekspozycji kredytowych, rodzaj produktów, rodzaj klientów, zmiany zachodzące w otoczeniu banku. Jedne banki będą stawiały mniejsze wymagania kredytobiorcom w zamian za wyższą cenę kredytu, inne natomiast będą stawiały wyższe wymagania, ale cena kredytu będzie niższa. Cena kredytu zależy od ryzyka kredytowego ponoszonego przez bank. Racjonalny klient powinien więc szukać kredytu, który będzie dopasowany do jego potrzeb i który będzie najtańszy.

Banki stosują uproszczoną lub standardową ocenę zdolności kredytowej klientów detalicznych. Od 2013 r. banki mogą stosować uproszczone zasady oceny zdolności kredytowej w przypadku udzielanych klientom detalicznym [Rekomendacja T dotyczaca dobrych praktyk..., 2013: 20, dostęp: 15.03.2017]:

a) kredytów i pożyczek ratalnych, dla których kwota kredytu lub pożyczki nie przekracza wartości czterokrotności przeciętnego miesięcznego wynagrodzenia w sektorze przedsiębiorstw,

b) kredytów i pożyczek - dla klientów o współpracy z bankiem trwającej od co najmniej sześciu miesięcy, dla których kwota kredytu lub pożyczki nie przekracza sześciokrotności przeciętnego miesięcznego wynagrodzenia w sektorze przedsiębiorstw,

- dla klientów o współpracy z bankiem trwającej od co najmniej dwunastu miesięcy, dla których kwota kredytu lub pożyczki nie przekracza dwunastokrotności przeciętnego miesięcznego wynagrodzenia w sektorze przedsiębiorstw, 
- dla pozostałych klientów, dla których kwota kredytu lub pożyczki nie przekracza przeciętnego miesięcznego wynagrodzenia $\mathrm{W}$ sektorze przedsiębiorstw.

Ocena zdolności kredytowej pozwala określić maksymalną kwotę kredytu, która w opinii kredytodawcy jest bezpieczna. Prawidłowo przeprowadzona ocena hamuje nadmierny apetyt na kredyt ze strony kredytobiorcy. Chroni go przed nadmiernym zadłużeniem, które definiowane jest jako ,przewaga bieżących i przyszłych obciążeń finansowych podmiotu gospodarczego nad jego przychodami do dyspozycji, oraz niedoborem aktywów konsumenta, które mogłyby zostać spieniężone celem spłaty długów" [Gębski 2013: 83-108].

Dopuszczalny poziom zadłużenia wyznaczany jest głównie na podstawie dochodu, kosztów, wartości zabezpieczenia oraz okresu kredytowania. Wydłużenie okresu kredytowania pozwala podnieść zdolność kredytową, ale za cenę wzrostu kosztu kredytu. Wysokość raty spłaty kredytu nie może przekraczać przyjętego przez bank w polityce kredytowej wskaźnika.

Dla kredytów detalicznych poziom dopuszczalnego zadłużenia banki określają na podstawie wskaźnika DTI (debt to income - dług do dochodu) dla kredytów bez zabezpieczenia, oraz LTV (loan to value - kredyt do zabezpieczenia) dla kredytów z zabezpieczeniem. Względna wysokość zadłużenia mierzona wskaźnikiem DTI jest miarą znacznie trafniejszą niż wartości bezwzględne.

Na podstawie wskaźnika DTI można przyjąć, że bezpieczne zadłużenie występuje wtedy, gdy nie przekroczony zostanie limit zadłużenia. Rekomendacja $\mathrm{T}$ mająca zastosowanie do kredytów konsumpcyjnych wprowadzona w 2010 r., ograniczyła wysokość raty spłaty kredytu do 50\% miesięcznych dochodów netto kredytobiorcy. Rekomendacja została wydana w reakcji na światowy kryzys finansowy i miała na celu ograniczenie efektu spirali zadłużenia gospodarstw domowych [Garncarczyk i in. 2014]. Kredytobiorca, który miał już kredyty i ich raty osiągnęły poziom $50 \%$ jego dochodów miesięcznych, nie miał szansy na zaciągniecie kolejnego zobowiązania kredytowego w banku. W lepszej sytuacji znaleźli się kredytobiorcy zarabiający więcej niż średnia krajowa. Dla nich maksymalna miesięczna kwota raty kredytu nie mogła być wyższa niż $65 \%$ miesięcznych dochodów netto [Rekomendacja $T$ dotycząca dobrych praktyk..., 2010: 22, dostęp: 10.02.2017].

W wyniku nowelizacji Rekomendacji T w 2013 r. KNF odszedł od sztywnego regulowania wskaźnika DTI - chociaż podtrzymał ograniczenie dostępu do kredytów udzielanych według uproszczonych zasad, ograniczając ich wysokość i wiążąc ją z okresem wcześniejszej współpracy konsumenta z bankiem [Rekomendacja T dotyczaca dobrych praktyk..., 2010: 20, dostęp: 10.02.2017]. Mimo pozostawienia wolnej ręki bankom w zakresie dopuszczalnego DTI duża część banków nadal „trzyma się” wskaźników zawartych w rekomendacji z 2010 r. 
Wskaźnikiem bezpiecznego zadłużenia stosowanym dla kredytów mieszkaniowych jest LTV określający stosunek wartości kredytu do wartości nieruchomości stanowiącej zabezpieczenie kredytu. W znowelizowanej w 2013 r. Rekomendacji S zawarto postanowienia o maksymalnym LTV dla nowo udzielanych kredytów i obowiązkowym wkładzie własnym. Zgodnie z punktem 10 Rekomendacji $\mathrm{S}$, ,W przypadku ekspozycji związanej z finansowaniem nieruchomości, bank nie powinien kredytować pełnej wartości nieruchomości stanowiącej przedmiot zabezpieczenia" [Rekomendacja $S$ dotyczaca dobrych praktyk..., 2013: 24, dostęp: 10.03.2017].

Z kolei zgodnie z punktem 15.7 Rekomendacji S „W przypadku ekspozycji kredytowych zabezpieczonych na nieruchomościach mieszkalnych wartość wskaźnika LTV w momencie udzielenia kredytu nie powinna przekraczać poziomu:

a) $80 \%$ lub,

b) $90 \%$ w przypadku, gdy część ekspozycji przekraczająca $80 \%$ LTV jest odpowiednio ubezpieczona, lub kredytobiorca przedstawił dodatkowe zabezpieczenie $\mathrm{w}$ formie blokady środków na rachunku bankowym lub poprzez zastaw na denominowanych w złotych dłużnych papierach wartościowych Skarbu Państwa lub NBP" [Rekomendacja S dotyczaca dobrych praktyk..., 2013: 31, dostęp: 10.03.2017].

\section{NIEPRAWIDŁOWOŚCI PO STRONIE BANKÓW}

Nieprawidłowości w procesie oceny zdolności kredytowej mają przede wszystkim charakter diagnostyczny i występują w fazie przedkontraktowej. Główne nieprawidłowości w procesie oceny zdolności kredytowej klientów detalicznych polegają na:

- zbyt niskich buforach bezpieczeństwa,

- zaniżonych kosztach utrzymania,

- zbyt długim okresie kredytowania,

- niewypełnianiu obowiązków informacyjnych wobec klientów.

Banki przy ocenie zdolności kredytowej przyjmują zbyt niskie bufory bezpieczeństwa, co oznacza niedoszacowanie ryzyka stopy procentowej w długiej perspektywie. Dlatego KNF wydał zalecenie, aby minimalna wielkość bufora była nie niższa niż 2.5 pp. Podobną rekomendację wydał Bank Anglii w 2014 r., zalecając, aby przy badaniu zdolności kredytowej banki sprawdzały, czy klient jest w stanie spłacać kredyt przy oprocentowaniu o 3 pp. wyższym niż aktualne. Jest to szczególnie ważne na polskim rynku mieszkaniowym na którym oprocentowanie kredytów hipotecznych jest zmienne a poziom stóp procentowych jest 
obecnie na historycznie niskim poziomie. Sytuacja taka tworzy wysokie ryzyko kredytowe dla kredytobiorców i banków w przyszłości.

Kolejną nieprawidłowością $\mathrm{w}$ procesie oceny zdolności kredytowej jest przyjmowanie kosztów utrzymania na zbyt niskim poziomie, nieadekwatnym do kosztów faktycznie ponoszonych przez kredytobiorców. Zgodnie z zaleceniami KNF-u minimalny poziom kosztów utrzymania nie powinien być niższy od minimum socjalnego publikowanego przez Instytut Pracy i Spraw Socjalnych dla różnych typów gospodarstw domowych. Zaniedbania banków polegają w tym przypadku na tym, że albo nie aktualizują kosztów utrzymania albo nie różnicują ich w ujęciu regionalnym. Banki w 2014r. udzieliły aż 47,6\% ogólnej liczby kredytów przy przyjęciu w momencie ich udzielenia kosztów utrzymania na poziomie niższym lub równym minimum socjalnego [Raport o sytuacji banków w 2014 r., 2015: 79, dostęp: 15.03.2017].

Inną złą praktyką banków jest nadmierne wydłużanie okresu kredytowania (nachodzące na wiek emerytalny kredytobiorcy) i przekraczanie przeciętnej długości trwania życia. Według stanu na koniec 2015 r. w portfelach banków znajdowało się aż 508,4 tys. kredytów o łącznej wartości 118,2 mld zł, w przypadku których ostateczny termin spłaty przypadał na wiek emerytalny kredytobiorcy (stanowiły one ponad $25 \%$ ogólnej liczby oraz ponad 30\% ogólnej wartości portfela kredytowego) [Raport o sytuacji banków w 2014 r., 2015: 109, dostęp: 15.03.2017].

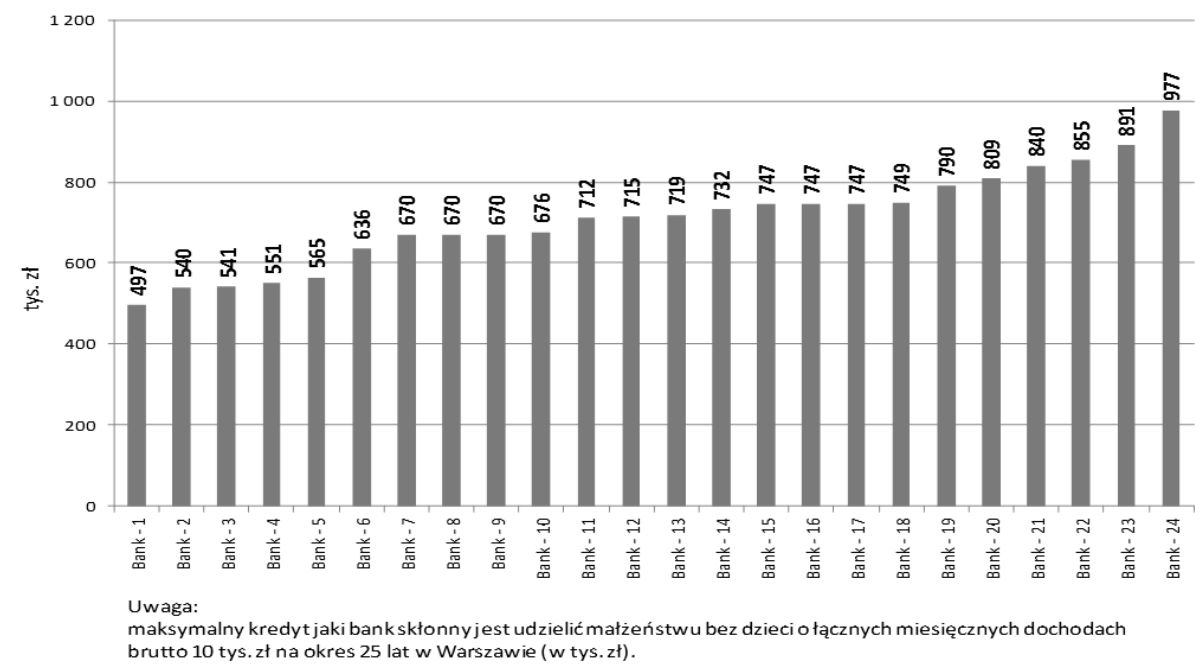

Wykres 1. Dostępna maksymalna kwota kredytu hipotecznego w 2015 r.

Źródło: Raport o sytuacji banków w 2015 r. [2016: 108, dostęp: 15.03.2017]. 
Banki w Polsce stosują znacznie bardziej liberalne zasady kredytowania aniżeli w Wielkiej Brytanii czy Irlandii, gdzie maksymalna kwota kredytu nie może przekraczać 4,5 lub 3,5 krotności łącznych rocznych dochodów kredytobiorcy [Raport o sytuacji banków w 2015 r., 2016: 108, dostęp: 15.03.2017]. W Polsce z grupy objętej badaniem KNF-u tylko jeden bank oferował kredyt na maksymalną kwotę mniejszą niż 4,5 krotność rocznych dochodów - najwięcej banków oferowało kredyt o wartości 6 krotności rocznych dochodów, a „rekordzista" ponad 8 (wykres 1 ).

Reasumując, rynek kredytów mieszkaniowych charakteryzują nadmiernie liberalne zasady udzielania kredytów i zbyt wysoka dostępność kredytowa. Sytuacja taka jest niebezpieczna, ponieważ może prowadzić do nadmiernego zadłużenia i wzrostu cen nieruchomości.

Niewypełnianie obowiązków informacyjnych występują szczególnie w działalności pośredników kredytowych. Zgodnie z ustawą o kredycie konsumenckim pośrednik finansowy zobowiązany jest przed zawarciem umowy o kredyt przekazać konsumentowi na trwałym nośniku informacje, jaki ma zakres umocowania do wykonywania czynności faktycznych i prawnych, z jakimi instytucjami kredytowymi współpracuje i ile wynoszą koszty pośrednictwa w fazie przygotowania, oferowania, zawierania i wykonywania umowy kredytowej i czy otrzymuje wynagrodzenie od kredytodawcy [Ustawa z dnia 12 maja 2011 r. ...]. Zazwyczaj w fazie przedkontraktowej konsumenci tych informacji nie otrzymują - informacje te stają się dostępne dopiero po otrzymaniu podpisanej w imieniu banku umowy kredytowej.

Pośrednicy nie przekazują bankom informacji na temat opłat pobranych od klientów w ramach zawartej umowy kredytowej. Zjawisko to ma znaczenie szczególnie wtedy, gdy w procedurę oferowania zaangażowany jest więcej niż jeden pośrednik. Zniekształca ono informację na temat całkowitych kosztów kredytu i utrudnia konsumentom podejmowanie decyzji.

W procesie kredytowania, poza niewypełnianiem obowiązków informacyjnych, występują jeszcze inne, mniej powszechne nieprawidłowości. Należą do nich utrudnienia w korzystaniu z prawa do odstąpienia od umowy i obciążanie kredytobiorców nadmiernie wysokimi kosztami kredytu. Zgodnie z art. 13 ustawy o kredycie konsumenckim zarówno bank jak i pośrednik zobowiązani są do podania konsumentowi na trwałym nośniku katalogu informacji, w tym wszystkich o kosztach kredytu i prawie do odstąpieni od umowy kredytu. Zdarza się, że klienci nie mogą wykonać prawa do odstąpienia od umowy zawartej z udziałem pośrednika ze względu na szczególną konstrukcje umowy. Praktyki uniemożliwiające odstąpienie od umowy, polegają na przekazaniu klientowi umowy dopiero po upływie 14 dni lub na odmowie zwrotu przez pośrednika kwoty wynikającej z pośrednictwa a kredytowanej przez bank i ponoszonej przez klienta [Pismo Przewodniczacego Komisji Nadzoru Finansowego z 21 listopada 2016 r., dostęp: 30.03.2017]. 
Na zawyżanie kosztów kredytu wpływa sposób ich naliczania. Koszty pośrednictwa, prowizja banku, ubezpieczenie są zazwyczaj kredytowane. Kredytowanie kosztów kredytu prowadzi do ich zawyżania. Klienci nie reagują na to, ponieważ koszty te są doliczane do kwoty kredyty i rozkładane na raty.

Nieprawidłowości $\mathrm{w}$ procesie kredytowania są powodem interwencji organów nadzoru. Europejski Urząd Nadzoru Bankowego (EBA) w dokumencie z 28 września 2016 r. zawierającym wytyczne dotyczące polityki i praktyk wynagradzania pracowników zajmujących się sprzedażą produktów bankowych klientom detalicznym uznał, że niewłaściwy system wynagradzania pracowników i pośredników sprzedażowych jest zasadniczym źródłem ryzyka dla sektora bankowego i wezwał banki do wprowadzenia działań naprawczych do 13 stycznia 2018 r. Uznał również, że główną przyczyną niedopasowania usług finansowych do potrzeb klientów są niewłaściwe zasady wynagradzania pracowników sprzedażowych.

Podobne kroki podjęła Komisja Nadzoru Finansowego. W piśmie Przewodniczącego Komisji Nadzoru Finansowego z 21 listopada 2016 r. (DOK/WPRII/0735/8/1/2016/EK) KNF zobowiązał banki do podjęcia niezbędnych działań $\mathrm{w}$ celu wyeliminowania zidentyfikowanych nieprawidłowości w praktyce banków i pośredników oraz zapewnienia należytych standardów w tym zakresie do 30 czerwca 2017 r. Ponadto KNF wyraził oczekiwanie, że oceny praktyk sprzedażowych będą prowadzone przez banki regularnie.

Dużą część nieprawidłowości w ocenie zdolności kredytowej konsumentów planujących sfinansowanie zakupu mieszkania kredytem hipotecznym ogranicza uchwalona ustawa z dnia 23 marca 2017 r. o kredycie hipotecznym oraz o nadzorze nad pośrednikami kredytu hipotecznego i agentami [Ustawa $\mathrm{z}$ dnia 23 marca 2017 r. ...].

Ustawa ma na celu wdrożenie postanowień unijnej dyrektywy MCD w sprawie konsumenckich umów o kredyt związanych z nieruchomościami mieszkalnymi. Zmiany wprowadzone ustawą ograniczają część opisanych powyżej nieprawidłowości. Nowe przepisy uniezależniają m.in. wynagrodzenie osób dokonujących oceny zdolności kredytowej od ilości zaakceptowanych wniosków. Ma to zapobiec sytuacji, gdy pracownik banku lub SKOK-u podwyższa zdolność kredytową klienta, aby zwiększyć swoje wynagrodzenie.

W ustawie poświęcono sporo uwagi procesowi badania zdolności kredytowej. Ryzyko błędów w procedurze oceny zdolności kredytowej zostało przerzucone na bank. Jeśli proces badania zdolności kredytowej nie zostanie przeprowadzony prawidłowo, kredytodawca nie będzie mógł odstąpić od umowy o kredyt lub jej zmienić, chyba że jest to korzystne dla klienta i wyraża on na to zgodę. Dotyczy to także sytuacji, gdy kredytobiorca przedstawił niekompletne informacje przed zawarciem umowy $-\mathrm{z}$ tego powodu kredytodawca nie będzie mógł wypowiedzieć umowy. 


\section{NIEPRAWIDŁOWOŚCI PO STRONIE KONSUMENTÓW}

Także konsumenci swoim zachowaniem mogą wpływać negatywnie na rzetelność wyniku oceny zdolności kredytowej. Zarówno po stronie kredytodawcy jak i kredytobiorcy istnieje przestrzeń dla działań lub zaniechań, które wypaczą wynik oceny. Nieprawidłowości ze strony klientów polegają m.in. na zatajaniu informacji o zaciągniętych pożyczkach, liczbie osób na utrzymaniu, wysokości osiąganych dochodów i ponoszonych kosztach utrzymania. Nieprawidłowości ze strony kredytobiorców nie są wcale rzadkie a skala nadużyć na rynku finansowym jest duża. Od lat na pierwszym miejscu, na liście nadużyć ze strony klientów znajdują się wyłudzenia przy wykorzystaniu fałszywych/skradzionych dokumentów lub informacji. Tego rodzaju nadużycia wskazało aż 74\% respondentów w badaniu przeprowadzonym przez Konferencję Przedsiębiorstw Prywatnych w Polsce i Ernst \& Young i jest to o $11 \%$ więcej niż w roku poprzednim [Nadużycia w sektorze finansowym..., 2016: 8].

Warunkiem rzetelnie przeprowadzonej oceny zdolności kredytowej jest wysoka jakość informacji o sytuacji kredytobiorcy. Tylko pełna i prawdziwa informacja umożliwia właściwą ocenę zdolności do spłaty długu. Niestety, jak pokazują wyniki badań opracowane przez A. Lewicką-Strzałecką, wśród konsumentów występuje niemała tolerancja dla zatajania informacji uniemożliwiających wzięcie kredytu (badanie przeprowadzone zostało metodą telefonicznego sondażu przez firmę Pactor Sp. z o.o. na zlecenie Konferencji Przedsiębiorstw Finansowych na ogólnopolskiej, reprezentatywnej 1000-osobowej próbie respondentów w wieku powyżej 18 lat, w lutym 2016 r.) [Lewicka-Strzałecka 2016: 17].

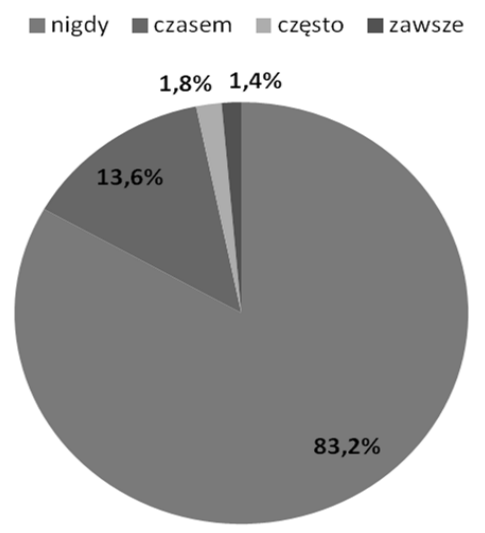

Wykres 2. Czy można usprawiedliwiać informację, gdy ktoś zataja informację uniemożliwiającą wzięcie kredytu?

Źródło: Lewicka-Strzałecka [2016: 11]. 
Prawie 20\% badanych mniej lub bardziej akceptuje, gdy ktoś ukrywa informację uniemożliwiającą wzięcie kredytu (wykres 2). Najwyższa akceptacja nieuczciwych zachowań występuje w grupie najmłodszych badanych (18-29 lat), z wykształceniem gimnazjalnym lub podstawowym, prowadzących własny biznes, o niskich dochodach, mieszkających w miastach powyżej 500 tys. mieszkańców i mających problemy ze spłatą kredytu [Lewicka-Strzałecka 2016: 14].

Motywacje konsumentów do ukrywania informacji mogą być różne. Mogą one wynikać $\mathrm{z}$ chęci ochrony prywatności, ale też z pragnienia zdobycia pieniędzy za wszelką cenę. Jednak bez względu na powody takich zachowań zatajanie informacji podnosi ryzyko podjęcia złej decyzji przez konsumenta. Oczywiście nie oznacza to, że w każdym przypadku konsument postępuje nieracjonalnie. Jeżeli np. może liczyć na pomoc rodziny albo osiąga dochody nierejestrowane, to jego sytuacja finansowa jest naprawdę inna (lepsza) niż ta, którą może przedstawić w oficjalnych dokumentach. Jednak taka sytuacja nakłada na konsumenta obowiązek dużo większej ostrożności, ponieważ całe ryzyko podjęcia złej decyzji spada na niego. W takim przypadku konsument powinien posiadać cechy profesjonalisty.

Relację między konsumentem a bankiem można rozpatrywać przez pryzmat teorii gier [Dixit i Nalebuff 2009: 86-124]. Zasadne jest przyjęcie założenia, że w grze o kredyt stroną słabszą jest konsument. Skoro tak, wynik gry będzie dla niego lepszy, jeśli będzie współpracował a nie konfrontował się z bankiem. $\mathrm{W}$ procesie oceny zdolności kredytowej duże znaczenie ma nastawienie konsumenta do banku. Jeżeli konsument traktuje bank jak przeciwnika, to będą starał się tego przeciwnika ograć, aby wszelkim sposobami zdobyć kredyt. Z takiego podejścia nie wyniknie dla konsumenta nic dobrego - nawet jeśli uda mu się zdobyć kredyt to wpędzi go on w kłopoty finansowe związane $\mathrm{z}$ jego spłatą. Jeżeli konsument będzie starał się być sprytniejszy od banku, to poniesie klęskę, ponieważ rozsądnie rzecz biorąc jest stroną słabszą i w konfrontacji z bankiem (profesjonalistą) nie ma szans. Natomiast jeżeli będzie traktował bank jak partnera to będzie współpracował $\mathrm{z}$ bankiem w celu znalezienia rozwiązania najlepiej dopasowanego do jego potrzeb. Wtedy istnieje szansa, że warunki kredytu będą do przyjęcia przez obie strony i obie strony na transakcji skorzystają Sposób postrzegania drugiej strony transakcji ma znaczenie i wpływa na wynik gry. Dla konsumentów lepiej jest gdy traktują bank jak partnera a nie przeciwnika.

Interesy banku i konsumenta nie są tożsame. Kryteria oceny zdolności kredytowej stosowane przez banki są dla konsumenta zbyt liberalne i niewystarczające. Konsekwencje złej decyzji nie mają dla banku tak dużego znaczenia jak dla konsumenta. Banki są silniejsze dlatego mogą sobie pozwolić na większe ryzyko w konkretnej transakcji. Dlatego w procesie podejmowania decyzji konsument powinien stosować znacznie niższe progi ostrożnościowe niż bank (dopuszczalny wskaźnik DTI). 
Także proces podejmowania decyzji kredytowych powinien ulec zasadniczej racjonalizacji. Zaniedbania ze strony konsumentów w procesie kredytowym są krytyczne [Dąbrowska 2012; Dąbrowska i in. 2015]. Świadczą o tym np. badania z których wynika, że co piąty kredytobiorca nigdy nie czyta umowy kredytu przed jej podpisaniem [Konsument na rynku ustug finansowych, 2012: 11, dostęp: 25.03.2017; Smyczek 2012: 185]. Oczywiście w tym kontekście rzetelność oceny zdolności kredytowej zależy od świadomości i kompetencji konsumentów. Poprawa w tym zakresie wymaga przede wszystkim edukacji konsumentów.

\section{PODSUMOWANIE}

Banki realizują model biznesowy nastawiony na agresywną sprzedaż bez rzetelnej oceny sytuacji ekonomicznej klienta i jego potrzeb. W ocenie zdolności kredytowej przyjmują zbyt niskie bufory bezpieczeństwa dla stopy procentowej i zaniżone koszty utrzymania. Nadmiernie wydłużają okres kredytowania i obciążają klientów nadmiernie wysokimi kosztami kredytu. Nie prowadzą należytej kontroli pośredników finansowych i w zbyt dużym stopniu tolerują zachowania naruszające prawa i interesy konsumentów. Osoby zaangażowane w proces sprzedaży nie mają odpowiedniego przygotowania merytorycznego, co utrudnia rzetelną ocenę zdolności kredytowej klientów.

$\mathrm{Z}$ drugiej strony postawy i zachowania konsumentów wykazują spory deficyt. Konsumenci cechują się wysokim stopniem niefrasobliwości, ignorancji i brakiem należytej staranności. W warunkach obustronnej asymetrii informacji kredytobiorcy jako słabsza strona transakcji powinni wykazywać więcej rozwagi i ostrożności w podejmowaniu decyzji. Działałoby to dyscyplinująco na kredytodawców i powstrzymywało ich przed stosowaniem nieuczciwych praktyk.

Poprawa działania rynku finansowania detalicznego wymaga zmian zarówno po stronie podaży, jak i popytu. Niezbędne są działania oczyszczające z nieuczciwych podmiotów po obu stronach rynku. $\mathrm{Z}$ tego względu na uznanie zasługują wszelkie inicjatywy podejmowane przez banki i instytucje finansowe w ramach samoorganizacji rynku, jak również inicjatywy adresowane do konsumentów, mające na celu podnoszenie ich świadomości i kompetencji. 


\section{BIBLIOGRAFIA}

Dąbrowska A., Bylok F., Janoś-Kresło M., Kiełczewski D., Ozimek I., 2015, Kompetencje konsumentów, PWE, Warszawa.

Dąbrowska A., 2012, Konsument na rynku ustug bankowych, [w:] A. Dąbrowska, M. Janoś-Kreslo (red.), Ochrona konsumentów na rynku ustug bankowych i telekomunikacyjnych, PWE, Warszawa.

Dixit A. K., Nalebuff B. J., 2009, Sztuka strategii. Teoria gier $w$ biznesie i życiu prywatnym, MT Biznes Sp. z o.o., Warszawa.

Dobosiewicz Z., 2011, Bankowość detaliczna, PWE, Warszawa.

Garncarczyk J., Mocek M., Skikiewicz R., 2014, Zachowania gospodarstw domowych na rynku ustug finansowych $w$ warunkach zmiennej koniunktury, CeDeWu.pl, Warszawa.

Gębski Ł., 2013, Nadmierne zadtużenie gospodarstw domowych - problem finansowo-prawny czy spoleczny?, „Gospodarka Narodowa”, nr 4(260).

Gnela B., 2012, Prawo handlowe dla ekonomistów, Wolters Kluwer Polska, Warszawa.

Knehans-Olejnik A. M., 2015, Ochrona i edukacja konsumentów na rynku kredytów hipotecznych $i$ konsumpcyjnych, DeCeWu.pl, Warszawa.

Konsument na rynku ushg finansowych, 2012, TNS Polska, https://www.google.pl/search?q= Konsument+na+rynku+us\%C5\%82ug+finansowych\%2C+TNS+Polska+2012.\&ie=utf-8\&oe $=$ utf-8\&client=firefox-b\&gfe_rd=cr\&ei=pcrXWIOXDdLi8Aea6bcw.

Lewicka-Strzałecka A., 2016, Moralność finansowa Polaków. Raport z badań, Konferencja Przedsiębiorstw Finansowych w Polsce, maj.

Małecki W., 2014, Przemiany sektora bankowego i ich konsekwencje, „Ekonomista”, nr 4.

Naduzycia w sektorze finansowym. Raport z badania. Edycja 2016, 2016, Konferencja Przedsiębiorstw Finansowych w Polsce i Ernst\&Young, Gdańsk-Warszawa, wrzesień.

Pismo Przewodniczacego Komisji Nadzoru Finansowego z 21 listopada 2016 r. (DOK/WPRII/0735/8/1/2016/EK), https://www.knf.gov.pl/Images/Dzialalnosc_bankow_ zwiazana_z_udzielaniem_kredytow_konsumenckich_i_wspolpracy_z_posrednikami_tcm7548787.pdf.

Raport o sytuacji banków w 2014 r., 2015, Urząd Komisji Nadzoru Finansowego, Warszawa, https://www.knf.gov.pl/Images/RAPORT_O_SYTUACJI_BANKOW_2014_12_tcm7541472.pdf.

Raport o sytuacji banków w 2015 r., 2016, Urząd Komisji Nadzoru Finansowego, Warszawa, https://www.knf.gov.pl/Images/RAPORT_O_SYTUACJI_BANKOW_2015_tcm7547215.pdf.

Rekomendacja $S$ dotyczaca dobrych praktyk $w$ zakresie zarządzania ekspozycjami kredytowymi zabezpieczonymi hipotecznie, 2013, KNF, czerwiec, http://www.knf.gov.pl/Images/Rekome ndacja_S_18_06_2013\%2E_tcm75-34880.pdf.

Rekomendacja $T$ dotyczaca dobrych praktyk $w$ zakresie zarzadzania ryzykiem detalicznych ekspozycji kredytowych, 2010, KNF, Warszawa, https://www.knf.gov.p1/Images/Rekomendacja \%20T_tcm75-18474.pdf.

Rekomendacja $T$ dotyczaca dobrych praktyk $w$ zakresie zarządzania ryzykiem detalicznych ekspozycji kredytowych, 2013, KNF, Warszawa, 2013, https://www.knf.gov.pl/Images/Rekomen dacjaT_tcm75-33586.pdf.

Rytelewska G., Huszczonek E., 2004, Zmiany w popycie na kredyt gospodarstw domowych, „Materiały i Studia", nr 172, Warszawa.

Smyczek S., 2012, Nowe trendy w zachowaniach konsumentów na rynkach finansowych, Placet, Warszawa. 
Świecka B., 2009, Niewypłacalność gospodarstw domowych. Przyczyny - skutki-przeciwdziałanie, Difin, Warszawa.

Ustawa z dnia 23 marca 2017 r. o kredycie hipotecznym oraz o nadzorze nad pośrednikami kredytu hipotecznego i agentami, Dz.U. 2017, poz. 819.

Ustawa z dnia 12 maja 2011 r. o kredycie konsumenckim, Dz.U. 2011, nr 126, poz. 715.

Ustawa z dnia 29 sierpnia 1997 r. - Prawo bankowe, Dz.U. 1997, nr 140, poz. 939.

Wałęga G., 2013, Kredytowanie gospodarstw domowych, PWE, Warszawa.

Wiatr M. S., 2001, Indywidualne ryzyko kredytowe, [w:] W. J. Jaworski, Z. Zawadzka (red.), Bankowość. Podręcznik akademicki, Poltext, Warszawa.

Wójciak M., 2007, Metody oceny ryzyka kredytowego, PWE, Warszawa.

\title{
THE INCORRECTNESS IN ASSESSMENT PROCEDURE OF CREDITWORTHINESS
}

\begin{abstract}
The correct assessment of consumer credit ability is in interest of creditor and debtor and also increase stability of financial system. The article point out the major incorrectness in assessment of creditworthiness, occurring both on consumer and bank side. There are low safety buffer of bank rates, low costs of living, excessive period of credit, failure in information delivery and hidden information by consumers. The text includes the set of corrective and repair actions also, being at disposal of banks and consumer which increase efficiency of consumer credit ability assessment.
\end{abstract}

Keywords: creditworthiness assessment, consumer finance, consumer protection, consumer safety. 